\title{
PROBLEMATIKA GURU PENDIDIKAN AGAMA ISLAM DALAM PEMBELAJARAN PADA ANAK TUNA GRAHITA USIA SD AWAL
}

\author{
Rika Sa'diyah', Siti Khosiah Rochmah ${ }^{2}$ \\ Universitas Muhammadiyah Jakarta ${ }^{1}$, Universitas Sultan Ageng \\ Tirtayasa $^{2}$ \\ E-mail: ikafina@gmail.com²,skhosiah@yahoo.co.id²
}

Naskah diterima : 27 Januari 2017, direvisi : 10 Februari 2017, disetujui : 20 April 2017

\begin{abstract}
Abstrak
Anak tuna grahita termasuk anak berkebutuhan khusus (special need) yang sebelumnya dikenal dengan istilah tuna mental, cacat mental atau retalisasi mental. Anak tuna grahita usia SD awal adalah anak kelas 1-3 SD yang memiliki kecerdasan di bawah kecerdasan anak normal, yang tidak memungkinkan untuk mengikuti pelajaran atau pendidikan di sekolah umum karena intelegensi di bawah rata-rata anak normal, sehingga perkembangan berfikirnya sangat lamban. Peran guru PAI dalam membantu kesulitan anak tuna grahita usia SD awal agar memperoleh bekal untuk hidup di tengah-tengah masyarakat secara normal, termasuk perihal pengamalan agama penting diperhatikan mengingat Lembaga Pendidik dan Tenaga Kependidikan (LPTK) yang menghasilkan calon guru agama seperti Fakultas Tarbiyah tidak dibekali dengan berbagai keahlian khusus untuk mengajar di Sekolah Luar Biasa.
\end{abstract}

Key words: Tuna Grahita, Guru PAI, SLB

Pengutipan: Sa'diyah, Rika., Rochmah. (2017). Problematika Guru Pendidikan Agama Islam dalam Pembelajaran pada Anak Tuna Grabita Usia AD Awal. JMIE: Journal of Madrasah Ibtidaiyah Education, 1(1), 2017, 46-59. sd.v1i1.22. 


\section{PENDAHULUAN}

\section{Latar Belakang}

Anak tuna grahita usia SD awal adalah anak yang memiliki gangguan kecerdasan (IQ) dibawah 70, yang berada pada kelas 1-3 SD. Anak tuna grahita ini termasuk anak berkebutuhan khusus yang memiliki hak atas pendidikan karena pendidikan merupakan hak setiap warga negara Indonesia, sehingga pemerintah wajib menyediakan kesempatan seluas-luasnya kepada rakyatnya agar dapat memperoleh pendidikan yang berkualitas. Pembukaan UUD 1945 alinea 4 menyatakan bahwa negara bertujuan mencerdaskan kehidupan bangsa. Selanjutnya dalam Pasal 31 ayat 1 UUD 1945 disebutkan bahwa untuk mewujudkan tujuan tersebut, maka setiap warga negara memiliki hak untuk mendapatkan pengajaran. Secara operasional, bentuk dukungan pendidikan termaktub dalam Undang-undang Nomor 20 tahun 2003 tentang Sistem Pendidikan Nasional Pasal 5 yang menyatakan bahwa setiap warga negara memiliki hak yang sama untuk memperoleh pendidikan yang bermutu. Hak atas pendidikan ini berarti untuk semua warga negara baik yang normal maupun berkebutuhan khusus.

Anak berkebutuhan khusus (special need) merupakan istilah umum yang digunakan saat ini setelah penggunaan istilah anak luar biasa. Istilah anak berkebutuhan khusus menyatukan berbagai jenis kekhususan atau kelainan. Dengan kata lain anak berkebutuhan khusus adalah anak yang memiliki perbedaanperbedaan baik perbedaan interindividual maupun intraindividual yang signifikan dan mengalami kesulitan dalam berinteraksi dengan lingkungan sehingga untuk mengembangkan potensinya dibutuhkan pendidikan dan pengajaran khusus. Dengan demikian, penggunaan istilah anak berkebutuhan khusus lebih menitikberatkan pada kebutuhan anak untuk mencapai prestasi sesuai dengan potensinya, sedangkan anak luar biasa lebih menitikberatkan pada kondisi fisik, mental dan sosial-emosional. Terlepas dari kedua istilah ini, baik istilah anak berkebutuhan khusus maupun anak luar biasa kedua-duanya tentu memiliki tujuan yang sama yaitu membantu kesulitan anak agar memperoleh bekal untuk hidup di tengah-tengah masyarakat secara normal, termasuk dalam hal agama.

Agama penting untuk dikenalkan bagi anak berkebutuhan khusus dalam hal ini bagi anak tunagrahita usia SD awal karena agama sebagai penuntun hidup merupakan dasar pijakan yang akan memandu setiap tindakan umatnya agar tetap berjalan sesuai syariahnya. Dengan demikian, guru PAI berperan penting dalam mengenalkan pengetahuan dasar, diantaranya seperti pengenalan rukun Iman dan Islam beserta aplikasinya, tata cara berperilaku dan bersosialisasi yang baik sesuai norma agama.

Sebagai bagian yang berperan penting, guru PAI dalam proses pembelajaran harus mempertimbangkan dengan hati-hati faktor tingkat perkembangan dan cara belajar, serta kebutuhan dan minat anak dalam mengupayakan tercapainya tujuan pembelajaran. Terlebih secara empiris belum ada Lembaga Pendidik dan Tenaga Kependidikan (LPTK) seperti Fakultas Tarbiyah yang menghasilkan calon guru 
agama pada jenjang Sekolah Dasar. Adapun guru agama yang dihasilkan saat ini diperuntukkan bagi jenjang Menengah, itupun tidak dibekali dengan berbagai keahlian khusus untuk mengajar di Sekolah Luar Biasa. Oleh karena itu, kurikulum yang didesain harus mengakomodir kebutuhan anak yang berkebutuhan khusus karena berbeda dengan di sekolah umum.

Guru PAI harus lebih mengutamakan proses belajar dalam perspektif "menjadi" di atas perspektif "memiliki". Setiap proses pembelajaran adalah assimilasi pembelajaran (miximizing "student learning"). Jika perlu mengurangi porsi ceramah (miximizing "teacher teaching") dengan mengaktifkan anak untuk mencari dan menemukan serta aktifitas belajar sendiri, sehingga konsep metodologi pembelajaran yang terbangun adalah "pembelajaran" (learning) bukan "pengajaran" (teaching). Inilah tantangan yang dihadapi guru PAI untuk mengemas dan mengimplementasikan materi-materi Agama Islam yang tertuang dalam kurikulum kepada anak. Materi Agama Islam yang menyangkut ajaran keimanan, seperti iman kepada Allah atau hari kiamat, dan ibadah praktis, seperti sholat, puasa dan haji-umrah merupakan materi yang membutuhkan strategi khusus. Sementara pembelajaran yang berkualitas akan tercapai jika guru melibatkan seluruh indera anak secara optimal, seperti melihat, mendengar, menyentuh, merasa dan mencium. Gearheart (1981) mengatakan bahwa seorang anak dianggap berkelainan dalam hal ini kecacatan mental, apabila memerlukan persyaratan pendidikan yang berbeda dari rata - rata anak normal dimana IQ-nya dibawah rata-rata dari anak normal tersebut, maka mereka membutuhkan belajar secara efektif melalui program, pelayanan, fasilitas, dan materi khusus.

Penelitian sejenis tentang strategi pembelajaran Pendidikan Agama Islam di Sekolah Luar Biasa (SLB) pernah dilakukan diantaranya oleh Muhammad Khoddik mahasiswa Fakultas Tarbiyah UIN Sunan Kalijaga Yogyakarta dengan topik kajian "Strategi Pembelajaran Pendidikan Agama Islam bagi Peserta Didik SMPLB Tuna Rungu di SLB Yapenas Condong Catur Depok Sleman Yogyakarta" Dari hasil penelitian diperoleh data bahwa strategi pembelajaran yang dipakai dalam pembelajaran Pendidikan Agama Islam bagi peserta didik tuna rungu adalah ceramah, keteladanan, tanya jawab, pemberian tugas, dan drill atau latihan. Pendekatan yang dipakai adalah pendekatan individual, kelompok, dan pembiasaan. Dalam mendukung terlaksananya strategi dengan baik bagi peserta didik tunarungu, guru menggunakan pendekatan berbahasa dengan Metode Maternal Reflektif (MMR) yaitu metode pembelajaran yang memuat percakapan dari hati ke hati, percakapan linguistik, dan membiasakan peserta didik untuk menyimak, berbicara, membaca dan menulis sesuai kemampuan peserta didik dengan dibina oleh guru. Hambatan yang dihadapi dalam pembelajaran Pendidikan Agama Islam adalah berasal dari peserta didik, fasilitas dan media pembelajaran. Sedangkan pendukung proses pembelajaran Pendidikan Agama Islam adalah berasal dari guru pengajar yang profesional dalam bidang pengajaran bagi peserta didik tuna rungu, serta didukung dengan keadaan sekolah dan kelas yang kondusif untuk belajar. 
Desi Iriyani dalam penelitiannya tentang "Metode Pembelajaran Pendidikan Agama Islam pada Anak Tunagrahita di SLB B-C di YPAALB Langenharjo Sukoharjo," hasil penelitian menyatakan bahwa guru SLB B/C YPAALB Langenharjo dalam menyampaikan materi kepada peserta didik menggunakan beberapa metode pembelajaran diantaranya meliputi metode ceramah dan hafalan, demonstrasi, apersepsi, menyanyi dan metode latihan. Selain itu, guru dalam menyampaikan materi menggunakan bahasa yang sederhana dan dilakukan secara berulang-ulang. Titik Munawaroh dalam penelitiannya tentang "Problematika Belajar Pendidikan Agama Islam pada Anak Penyandang Tunagrahita di SLB B/C YPPLB Ngawi”, hasil penelitian mengemukakan bahwa guru dalam menyampaikan materi menggunakan beberapa metode pembelajaran, seperti metode ceramah dan hafalan, demonstrasi, menyanyi dan latihan.

Dari sejumlah permasalahan yang telah diteliti yang dilaporkan dalam bentuk karya ilmiah, belum diperoleh informasi tentang hasil penelitian problematika guru PAI dalam proses pembelajaran pada anak tuna grahita di SDLB. Dengan demikian, permasalahan ini layak untuk diteliti.

\section{KAJIAN LITERATUR DAN PEMBAHASAN Guru Pendidikan Agama Islam (PAI)}

Guru PAI adalah guru yang bertugas mengampu mata pelajaran Agama Islam. Salah satu tugas penting guru PAI adalah membuat peserta didik belajar dengan melaksanakan kegiatan pembelajaran yang efektif. Untuk dapat melaksanakan pembelajaran yang efektif guru PAI harus memahami bagaimana peserta didik belajar. Untuk dapat membuat peserta didik mau belajar, maka guru PAI harus mengatur lingkungan belajar yang memungkinkan peserta didik untuk belajar secara optimal. Agar peserta didik dapat belajar secara optimal, maka kegiatan pembelajaran sebagai inti dari pelaksanaan kurikulum harus benar-benar bermutu sebab mutu pendidikan dan atau mutu lulusan banyak dipengaruhi oleh mutu kegiatan pembelajaran. Jika mutu kegiatan pembelajarannya bagus, dapat diprediksi bahwa mutu lulusan bagus atau sebaliknya. Jika mutu kegiatan pembelajarannya tidak bagus, maka mutu lulusannya juga tidak bagus. Oleh karena itu, pelaksanaan kegiatan pembelajaran harus dirancang dengan baik, disesuaikan dengan kemampuan dan kebutuhan setiap individu dan didukung oleh kompetensi guru, media, sumber dan strategi pembelajaran yang memadai, sesuai dengan Standar Pelayanan Minimal.

Pendidikan Agama Islam sebagaimana dirumuskan oleh Puskur adalah upaya sadar dan terencana dalam menyiapkan peserta didik untuk mengenal, memahami, menghayati hingga mengimani, bertaqwa, dan berakhlak mulia dalam mengamalkan ajaran agama Islam dari sumber utamanya kitab suci Al Quran dan Hadits, melalui kegiatan bimbingan, pengajaran, latihan, serta penggunaan pengalaman. Arifin menambahkan bahwa Pendidikan Agama Islam merupakan bimbingan atau pimpinan secara sadaroleh pendidikyangbersumberkan pada nilai-nilai agama Islam, 
disamping menampakkan atau membentuk tingkah laku yang dijiwai dengan nilainilai agama, juga mengembangkan ilmu pengetahuan yang sejalan dengan nilai Islam. Lebih lanjut Zuhairini dkk, menjelaskan bahwa Pendidikan Agama Islam adalah usaha sadar yang dapat dilakukan seseorang atau lembaga pendidikan secara sadar untuk mengembangkan potensi peserta didik, baik yang bersifat jasmani maupun rohani berdasarkan ajaran Islam.

Tujuan pendidikan Agama Islam adalah untuk menumbuhkan dan meningkatkan keimanan, melalui pemberian dan pemupukan pengetahuan, penghayatan, pengamalan serta pengalaman peserta didik tentang agama Islam, sehingga menjadi manusia muslim yang terus berkembang dalam hal keimanan, ketaqwaannya kepada Allah SWT. serta berakhlak mulia dalam kehidupan pribadi, bermasyarakat, berbangsa dan bernegara, serta untuk dapat melanjutkan pada jenjang pendidikan yang lebih tinggi.

Pendidikan Agama Islam berfungsi untuk: 1) penanaman nilai ajaran Islam, 2) pengembangan keimanan dan ketakwaan kepada Allah SWT serta akhlak mulia, 3) penyesuaian mental peserta didik terhadap lingkungan, 4) pengamalan ajaran agama Islam dalam kehidupan sehari-hari, 5) pencegahan peserta didik dari hal-hal negatif budaya asing yang akan dihadapinya sehari-hari, 6) pengajaran tentang ilmu pengetahuan keagamaan secara umum sistem dan fungsionalnya, 6) penyaluran peserta didik untuk mendalami pendidikan agama ke lembaga pendidikan yang lebih tinggi.

Materi Pendidikan Agama Islam secara keseluruhan terbagi dalam empat cakupan: Al Quran dan Hadits, Aqidah, Akhlak, dan Fiqh. Empat aspek materi Pendidikan Agama Islam di atas menekankan adanya keseimbangan, keselarasan dan keserasian antara hubungan manusia dengan Allah SWT, hubungan manusia dengan diri sendiri dan hubungan manusia dengan alam sekitar.

Berdasarkan pengertian Pendidikan Agama Islam, maka dapat dipahami bahwa guru PAI adalah seseorang yang bertugas membimbing, mengarahkan dan mendidik anak dalam memperoleh pengetahuan Islam beserta keterampilannya untuk diamalkan dalam kehidupan sehari-hari guna menjadi manuasia yang sempurna (insan kamil).

\section{Pembelajaran}

"Mengelola pembelajaran" atau "mengajar" menurut pandangan para ahli diartikan sebagai berikut 1) Tyson dan Caroll dalam Syah mengartikan mengelola pembelajaran adalah "a way working with student, a process of interaction, the teacher does something to student; the students do something in return" (sebuah cara dan proses hubungan timbal balik antara guru dan peserta didik yang sama-sama aktif melakukan kegiatan). 2) Tardif dalam Syah menyederhanakan pengertian mengelola pembelajaran yakni "any action performed by an individual (the teacher) with the intention of facilitating learning in another individual (the learner)".

Pengertian ini menunjukkan bahwa mengelola pembelajaran (mengajar) 
adalah perbuatan yang dilakukan oleh seorang (guru) dengan tujuan membantu atau memudahkan orang lain (peserta didik) melakukan kegiatan belajar. 3) Gagne mengartikan mengajar sebagai bentuk pembelajaran (instruction). Menurutnya dalam mengelola pembelajaran (mengajar) seorang guru menentukan model pengajaran dan metode serta media yang digunakan.

Nasution secara sekilas menyatakan bahwa mengelola pembelajaran adalah usaha untuk menciptakan kondisi sedemikan rupa sehingga terjadi interaksi antara murid dan lingkungannya termasuk guru, alat pelajaran dan lain sebagainya dalam rangka pencapaian tujuan yang ditentukan. 4) Bagi Woolfolk, mengelola pembelajaran (mengajar) adalah suatu profesi di mana seseorang menggunakannya sebagai tanggung-jawab dari suatu pengalaman "ahli".

Menurutnya mengelola pembelajaran adalah suatu seni yang menuntut visi, intuisi, bakat, komitmen dan kreativitas yang senyatanya dimiliki ketika mengelola pembelajaran (mengajar) tersebut. Mengelola pembelajaran (mengajar) juga merupakan ilmu, karena menuntut adanya pengetahuan dan keterampilan yang dapat dipelajari.

5) Menurut Vargas, mengelola pembelajaran (mengajar) adalah merubah perilaku, yaitu membantu peserta didik untuk belajar, atau belajar lebih cepat, atau belajar lebih efisien dibanding mereka belajar sendiri.

Dalam konsep lama, mengajar adalah proses memberikan/menyampaikan pengetahuan dan keterampilan yang diperlukan kepada peserta didik. Konsep sekarang mengajar atau mengelola pembelajaran adalah memberikan pemahaman dan memandu peserta didik baik individu maupun kelompok, ini juga berarti mengajar atau mengelola pembelajaran adalah memfasilitasi peserta didik untuk mendapatkan pengalaman dan untuk tumbuh secara terus menerus menjadi orang dewasa.

Dari beragam definisi dapat disimpulkan bahwa mengelola pembelajaran adalah suatu aktifitas yang tersistem dari interaksi antara guru dengan peserta didik atau antara dosen dengan mahasiswa dan terintegrasi dalam sejumlah pengetahuan dan keterampilan untuk membantu atau memudahkan, memfasilitasi peserta didik melakukan kegiatan belajar. Inti dari mengelola pembelajaran adalah mengarah pada timbulnya perilaku belajar peserta didik. Untuk itu diperlukan serangkaian pengetahuan dan keterampilan yang harus dimiliki seorang guru/dosen.

\section{Tuna Grahita}

Tuna grahita merupakan istilah baru yang sebelumnya dikenal dengan istilah tuna mental, cacat mental atau retalisasi mental. Dari berbagai istilah yang berkembang, istilah di atas memiliki pengertian yang sama, yaitu anak yang mengalami hambatan dalam perkembangan mental. Departemen Pendidikan dan Kebudayaan (1984) menyebutkan bahwa anak tuna grahita adalah anak yang mempunyai kecerdasan di bawah kecerdasan anak normal, yang tidak memungkinkan untuk mengikuti pelajaran atau pendidikan di sekolah umum karena intelegensi di bawah rata-rata 
anak normal, sehingga perkembangan berfikirnya sangat lamban.

Ketunagrahitaan mengacu pada intelektual umum yang secara signifikan berada di bawah rata-rata. Peserta didik tunagrahita mengalami hambatan dalam tingkah laku dan penyesuaian diri. Semua itu berlangsung atau terjadi pada masa perkembangannya. Seseorang dikatakan tunagrahita apabila memiliki tiga indikator, yaitu: 1) keterhambatan fungsi kecerdasan secara umum atau di bawah rata-rata, 2) ketidakmampuan dalam prilaku sosial/adaptif, dan 3) hambatan perilaku sosial/ adaptif terjadi pada usia perkembangan yaitu sampai dengan usia 18 tahun.

Tingkat kecerdasan seseorang diukur melalui tes inteligensi yang hasilnya disebut dengan IQ (intelligence quotient). Tingkat kecerdasan biasa dikelompokkan ke dalam tingkatan sebagai berikut: 1) Tunagrahita ringan memiliki IQ 70-55, 2) Tunagrahita sedang memiliki IQ 55-40, 3) Tunagrahita berat memiliki IQ 40-25, 4) Tunagrahita berat sekali memiliki IQ $<25$

\section{Sekolah Dasar Luar Biasa}

SDLB merupakan bentuk satuan pendidikan dasar yang menyelenggarakan program pendidikan enam tahun di Sekolah Luar Biasa. SLB adalah lembaga pendidikan khusus yang menangani pendidikan untuk peserta didik yang memiliki ketidaksempurnaan fisik atau salah satu dari organ tubuhnya tidak berfungsi. Adapun batasan - batasan bahwa anak tergolong luar biasa atau cacat mental berkelainan adalah anak yang menyimpang dari rata - rata anak normal dimana mereka memiliki masalah pada mental, kemampuan - kemampuan sensorik, fisik dan neuromuskular, perilaku sosial dan emosional, maupun kemampuan berkomunikasi.

Sejak tahun 2000 dengan dicanangkannya EFA (education For All) di DakkarSinegal SLB ini merupakan salah satu lembaga pendidikan yang menyelenggarakan pendidikan inklusif. Dalam pelaksanaannya, pendidikan inklusif dapat diselenggarakan di sekolah-sekolah reguler maupun sekolah-sekolah luar biasa. Yang demikian itu, menandakan bahwa anak-anak dengan berbagai keragaman kelainan dapat memperoleh pendidikan layaknya anak-anak normal.

Sekolah Dasar merupakan salah satu Pada pasal 17 UU RI No.20 Tahun 2003 disebutkan bahwa pendidikan dasar berbentuk Sekolah Dasar (SD) dan Madrasah Ibtidaiyah (MI) yang sederajat serta Sekolah Menengah Pertama (SMP) dan Madrasah Tsanawiyah atau bentuk lain yang sederajat. Tujuan pendidikan Sekolah Dasar ini menurut pasal 2 keputusan Mendikbud No.0487/U/1992 tentang SD, yaitu memberikan bekal kemampuan dasar kepada peserta didik untuk melanjutkan ke sekolah Lanjutan Tingkat Pertama. SDLB sebagai lembaga khusus untuk anak-anak yang memiliki kebutuhan khusus sederajat dengan Sekolah Dasar pada umumnya, dimana pendekatan pembelajarannya menggunakan pendekatan tematik. 
Pada akhir tahun 1970 pemerintah mulai memberikan perhatian terhadap pentingnya pendidikan intergrasi (inklusif saat ini), kemudian kesuksesan pendidikan integrasi ini mendorong pemerintah mengeluarkan SK Mendikbud 1986 yang menyebutkan bahwa penyandang cacat yang memiliki kemampuan mesti diberi kesempatan untuk sekolah di reguler, namun sangat disayangkan setelah proyek ini selesai pelaksanaannya semakin berkurang terutama di Sekolah Dasar.

\section{Metode Penelitian}

Penelitian ini menggunakan studi kualitatif naturalistik yang dilaksanakan pada semester ganjil tahun pelajaran 2014/2015 di SDLB Pembina Tk I Cilandak Jakarta Selatan dengan unit analisis utama penelitian, yaitu problematika guru PAI dalam pembelajaran pada anak tuna grahita usia SD awal. Teknik pengumpulan data berupa observasi, wawancara, dan studi dokumentasi. Prosedur analisis data dilakukan dengan mengadakan reduksi, selanjutnya mengadakan display data yang didapat dari lapangan dan setelah mengadakan pengolahan dan pengamatan hasil penelitian selanjutnya dilakukan penyimpulan dan diakhiri dengan verifikasi untuk mendapat validitas kesimpulan akhir.

\section{HASIL ANALISIS}

Berdasarkan temuan hasil penelitian pada anak tunagrahita usia SD awal di SDLB Pembina Tk I, diperoleh informasi bahwa problematika guru PAI dalam proses pembelajaran meliputi:

\section{Perencanaan Pembelajaran}

Program pembelajaran SDLB meliputi Program Akademis, Program Khusus, Muatan Lokal dan Keterampilan. Program Akademis terdiri dari: Agama, PKn, Bahasa Indonesia, Matematika, IPS, dan IPA. Program Khusus untuk tuna grahita adalah Bina Diri. Program Muatan Lokal adalah Pendidikan Lingkungan Jakarta (PLKJ). Program Khusus hanya untuk satuan pendidikan TKLB, SDLB dan SMPLB. Pogram khusus Bina Diri meliputi: a) latihan koordinasi motoris dan kontrol meliputi: berjalan, membawa/ mengangkat benda, membuka dan menutup, b) mengurus diri sendiri, meliputi: menggunakan sendok, menuangkan biji-bijian dan air, mencuci tangan, membersihkan sepatu, menggunakan cermin, dan menggosok gigi, c) membersihkan lingkungan sekitar, meliputi: membersihkan lingkungan di dalam rumah/sekolah, lingkungan di luar rumah/sekolah, tata cara bergaul dan sikap dalam masyarakat, d) merawat diri, meliputi latihan makan, berpakaian, menjaga diri, dan mengatasi urusan pribadi, e) latihan sensori motor, meliputi: sensori penglihatan, sensori perabaan, sensori pendengaran, sensori terhadap berat, panas, penciuman dan rasa.

Berdasarkan hasil pengamatan dan dokumentasi diketahui bahwa dalam pelaksanaannya, perencanaan pembelajaran dimulai dari perencanaan tahunan 
hingga harian. Perencanaan tahunan adalah perencanaan kegiatan yang akan dilakukan selama satu tahun yang terdiri atas 14 tema, yaitu: a) Diri sendiri, b) Keluarga, c) Lingkungan, d) Transportasi, e) Kesehatan, Kebersihan dan Keamanan, f) Hewan dan Tumbuhan, g) Pekerjaan, h) Gejala Alam dan Peristiwa, i) Rekreasi, j) Negara, dan k) Alat Komunikasi.

Selanjutnya perencanaan semesteran merupakan penjabaran dari perencanaan tahunan. Perencanaan semesteran ini terbagi menjadi dua semester, yaitu semester satu dan semester dua. Dalam satu semester terdapat empat tema, yaitu Diri Sendiri, Keluarga, Lingkungan, serta Hewan dan Tumbuhan. Tema menjadi topik pembahasan dalam pembelajaran yang rata-rata memiliki alokasi waktu 20 jam. Tema menjadi satu pendekatan dan sebagai sarana dalam membekali program akademis anak, yang terdiri atas beberapa mata pelajaran, yaitu: bahasa Indonesia, Matematika, IPA, IPS, dan Pkn.

Dari program semesteran kemudian dijabarkan ke dalam Silabus dan Rencana Pelaksanaan Pembelajaran (RPP). Silabus dan RPP dibuat oleh setiap guru kelas, namun tidak memasukkan bidang pengembangan Agama dan kebutuhan setiap anak, sehingga masing-masing anak kebutuhan khususnya belum terpenuhi.

Dari hasil pengamatan dan studi dokumentasi juga diketahui bahwa isi RPP belum dikaitkan dengan tema yang dibahas termasuk strategi yang akan diterapkan. RPP yang disusun belum menunjukkan langkah pembelajaran yang konkret (umum \& operasional). Bahkan jika guru kelas berhalangan hadir, dapat digantikan oleh guru lain meskipun tanpa panduan RPP yang jelas.

Idealnya, perencanaan pembelajaran memasukkan semua bidang pengembangan termasuk bidang pengembangan keagamaan meskipun telah ada guru PAI yang menangani secara khusus. Hal ini mengingat bahwa guru PAI yang ditugaskan di SLB belum dibekali seperangkat pengetahuan yang berkaitan dengan Pendidikan Kekhususan. Selain itu, perencanaan pembelajaran disusun oleh guru dengan memperhatikan karakteristik dan kebutuhan anak.

Perencanaan pembelajaran sangat penting sebagai acuan dalam melaksanakan kegiatan pembelajaran. Perencanaan pembelajaran yang baik diantaranya harus mencakup: a) Perencanaan Tahunan, b) Perencanaan Semesteran, c) Perencanaan Bulanan, d) Perencanaan Mingguan, dan e) Perencanaan Harian.

Dalam merancang kegiatan pembelajaran di SDLB hendaknya juga memperhatikan hal-hal seperti di bawah ini: a) menetapkan tujuan, b) merencanakan pengelolaan kelas; termasuk mengatur lingkungan fisik dan sosial, c) menetapkan dan mengorganisasikan bahan/materi; topik apa yang ingin diajarkan kepada anak, d) merencanakan strategi pendekatan kegiatan pembelajaran; bagaimana bentuk kegiatannya, apakah anak mendapat kesempatan untuk berperan aktif dalam pembelajaran, e) merencanakan prosedur kegiatan pembelajaran; bagaimana bentuk dan urutan kegiatannya, apakah kegiatan itu sesuai untuk semua anak, dan bagaimana anak mencatat, mendokumentasikan, dan menampilkan hasil belajarnya, f) merencanakan penggunaan sumber dan media belajar; sumber belajar mana 
yang akan digunakan, media apa yang sesuai dan tidak membahayakan anak, g) merencanakan penilaian; bagaimana cara anak telah menyelesaikan tugasnya dalam suatu proses pembelajaran, dan apa bentuk tindak lanjut yang diinginkan.

\section{Pelaksanaan Pembelajaran}

\section{a. Pembukaan}

Pelaksanaan pembelajaran pada prinsipnya dilakukan dalam tiga tahap, yaitu pembukaan, kegiatan inti dan penutup. Kegiatan pembukaan mengacu pada RPP yang telah dibuat, tetapi dalam pelaksanaannya belum sesuai dengan acuan tersebut. Sebelum kegiatan pembelajaran berlangsung, guru mengkondisikan anak agar dapat mengikuti materi yang akan dibahas. Pengkondisian anak seringkali menjadi kendala bagi guru karena hampir sebagian besar anak memiliki perbedaan minat, perhatian dan kebutuhan. Salah seorang guru PAI mengungkapkan bahwa kurikulum Pendidikan Agama Islam merupakan hasil duplikasi dari sekolah regular. Kurikulum hanya berfungsi sebatas rambu-rambu, termasuk RPP guna memenuhi syarat dan tuntutan administrasi. RPP diimplementasikan secara kondisional, dalam arti tidak konsisten dengan perencanaan. Hal ini disebabkan adanya heterogenitas anak yang tidak memungkinkan jika RPP dan ujian didesain secara individual.

Di sisi lain, hasil pengamatan menunjukkan tentang beberapa perilaku yang ditunjukkan anak sebelum kegiatan pembelajaran dimulai, diantaranya seperti: anak berlari-lari, menangis, teriak-teriak, tiduran, bengong, dan asyik bermain sendiri. Perilaku anak yang beragam kadangkala memancing emosi guru, terlebih rasio antara guru dan anak tidak sebanding karena rata-rata 1:5 bahkan ada yang 1:8 atau 1:10 padahal idealnya adalah 1:4. Untuk beban guru PAI, rasio antara guru dan anak lebih tidak rasional. Jumlah anak yang beragama Islam tahun pembelajaran 20132014 sebanyak 291, sedangkan guru Agama yang tersedia hanya 2 orang yang resmi diangkat oleh kementerian Agama. Oleh karena itu, pembelajaran Agama Islam di SDLB kadang-kadang ditangani secara langsung oleh guru kelas. Hal ini disebabkan oleh faktor beban guru PAI telah melampaui beban wajib. Sementara kelebihan jam mengajar tidak diberikan kompensasi karena keterbatasan kemampuan keuangan sekolah sebagaimana disampaikan oleh salah seorang guru PAI melalui wawancara yang menyebutkan bahwa terdapat deskriminasi penghargaan terhadap guru yang diangkat oleh Pemda dan Kemenag. Upaya untuk mengatasi deskriminasi sering dilakukan tetapi belum ada solusi, sehingga berpengaruh terhadap motivasi dan kinerja guru, bahkan mengakibatkan frustasi.

\section{b. Kegiatan Inti}

Kegiatan pembelajaran di SDLB belum mengacu pada RPP yang telah direncanakan, meskipun model kurikulum yang digunakan adalah model duplikasi (mengadopsi kurikulum anak normal). Pendekatan yang digunakan lebih menuntut pada pendekatan kontekstual dan situasional, sehingga pelaksanaan 
pembelajaran bisa sangat berbeda dengan apa yang sudah direncanakan. Hal ini tampak pada saat kegiatan pembelajaran akan dimulai, guru terlebih dahulu mengamati kondisi kelas dan menanyakan benda yang dibawa serta disukai anak. Oleh karena itu, perencanaan yang dibuat guru seringkali hanya untuk memenuhi tuntutan administrasi. Padahal berdasarkan Kurikulum Tingkat Satuan Pendidikan (KTSP), model pembelajaran pada peserta didik tunagrahita mulai TKLB-SMALB menggunakan pendekatan tematik. Salah seorang guru PAI melalui wawancara menyebutkan bahwa perencanaan yang didesain oleh guru seideal apapun, dalam pelaksanaannya akan sangat tergantung pada situasi dan kebutuhan masing-masing anak pada saat itu. Namun demikian, fakta menunjukkan bahwa pembelajaran masih tampak monoton dan konvensional. Guru lebih banyak menggunakan metode ceramah dibandingkan dengan metode pembelajaran lainnya yang memungkinkan mampu menciptakan suasana pembelajaran yang aktif, interaktif, kreatif, efektif, dan menyenangkan.

Media sebagai alat bantu untuk mempermudah anak dalam memahami materi PAI juga belum digunakan secara optimal. Padahal media yang menarik, mencolok dan berukuran besar akan sangat memotivasi anak bahkan mampu menstimulasi kegiatan pembelajaran yang menyenangkan. Selama ini guru belum pernah membuat media dari hasil kreatifitasnya dan media yang seharusnya diadakan oleh pihak sekolah selalu terkendala oleh terbatasnya anggaran, termasuk belum adanya bantuan dari Kementerian Agama. Hal ini terbukti bahwa dalam pengadaan Laboratorium Agama, guru PAI lebih menggandalkan hubungan kerja sama antara orang tua dan pihak sekolah melalui bantuan infak. Pernyataan ini didukung oleh hasil wawancara dari salah seorang guru PAI yang menyebutkan bahwa laboratorium Agama merupakan hasil kreatifitas dua guru PAI bukan bantuan dari pemerintah karena dana diperoleh dari hasil infak dan sumbangan komite.

Laboratorium Agama menjadi sarana dalam kegiatan pembelajaran PAI. Laboratorium Agama ini memiliki sarana yang memadai dan lebih banyak diakses oleh peserta didik SMP dan SMA. Ini disebabkan sistem pembelajaran di SD belum menerapkan moving class. Beberapa kegiatan pengembangan PAI selain kegiatan pembelajaran di kelas, meliputi: a) tadarus pagi 10 menit sebelum belajar dimulai, b) sholat dhuhur berjamaah setiap hari, c) mendengarkan ceramah/ta'lim (10 menit), d) bimbingan BTA (Baca Tulis Al-Qur'an), e) kursus kaligrafi f) membiasakan budaya Islami di lingkungan sekolah, g) pesantren ramadhan, h) Loketa (Lomba Ketrampilan Agama), i) PHBI (Maulid, Qurban, halal-bihal). Program Akademik Pendidikan Agama Islam mengikuti kurikulum (SK/KD) yang diterbitkan BNSP. Namun mulai tahun pembelajaran 2013/2014 SLB Negeri 1 Jakarta menggunakan kurikulum (SK/KD) yang telah direvisi oleh Kementerian Agama RI, Direktorat Pendidikan Agama Islam Pada Sekolah (Direktorat PAIS). 


\section{c. Penutup}

Pada kegiatan penutup, guru mengakhiri dengan kegiatan doa. Tidak ada kegiatan review dan informasi yang menjelaskan tentang kegiatan esok hari. Guru lebih mengkondisikan anak-anak kepada persiapan pulang.

Hakikatnya, proses pembelajaran berlangsung menurut pola umum pembelajaran yang terdiri atas: 1) kegiatan awal/pendahuluan; hal-hal yang dilakukan guru pada kegiatan awal antara lain adalah: a) mempersiapkan anak supaya tenang, b) memperbaiki cara duduk anak, c) membaca doa, d) mengabsen anak, dan e) appersepsi. 2) Kegiatan inti; pada kegiatan ini guru melakukan hahal sebagai berikut: a) melaksanakan apersepsi, b) menyajikan materi/bahan pelajaran, c) mengimplementasikan metode, sumber/media belajar, dan bahan latihan yang sesuai dengan kemampuan awal dan karakteristik anak, d) mendorong anak untuk terlibat secara aktif, e) mendemontrasikan penguasaan materi pelajaran dan relevansinya dalam kehidupan, f) mengelola pembelajaran kelompok yang kooperatif, g) membina hubungan antarpribadi, bersikap terbuka, toleran, dan simpati terhadap anak, menampilkan kegairahan dan kesungguhan, dan mengelola interaksi antarpribadi. 3) Melaksanakan evaluasi; a) melakukan penilaian selama kegiatan pembelajaran berlangsung dan setelah kegiatan pembelajaran selesai, baik secara lisan, tertulis, maupun melalui pengamatan, b) memberikan informasi tentang kegiatan yang akan dilakukan esok hari.

Prinsip pembelajaran yang belum dilakukan pada anak tunagrahita kelas SD awal ini, diantaranya: 1) prinsip kasih sayang; tuna grahita adalah peserta didik yang mengalami kelainan dalam segi intelektual, dimana inteligensi mereka di bawah rata-rata. Akibatnya, dalam tugas-tugas akademik yang menggunakan intelektual, mereka sering mengalami kesulitan. Dalam kegiatan pembelajaran, anak tuna grahita membutuhkan kasih sayang yang tulus dari guru. Guru hendaknya berbahasa yang lembut, sabar, rela berkorban, dan memberi contoh perilaku yang baik, ramah, dan supel, sehingga tumbuh kepercayaan dari anak, yang pada akhirnya mereka memiliki semangat untuk melakukan kegiatan dan menyelesaikan tugas-tugas yang diberikan guru. 2) Prinsip keperagaan; kelemahan anak tuna grahita antara lain adalah dalam hal kemampuan berfikir abstrak, mereka sulit membayangkan sesuatu. Dengan segala keterbatasannya itu, anak tuna grahita akan lebih mudah tertarik perhatiannya apabila dalam kegiatan pembelajaran menggunakan bendabenda konkrit maupun berbagai alat peraga (model) yang sesuai. Hal ini menuntut guru agar dalam kegiatan pembelajaran selalu mengaitkan relevansinya dengan kehidupan nyata sehari-hari. Oleh karena itu, anak perlu dibawa ke lingkungan sosial, maupun lingkungan alam. Apabila tidak memungkinkan, guru dapat membawa berbagai alat peraga. 3) Prinsip habilitasi dan rehabilitasi; dalam bidang akademik anak tuna grahita memiliki kemampuan yang terbatas, namun dalam bidang-bidang lainnya mereka masih memiliki kemampuan atau potensi yang masih dapat dikembangkan. Habilitasi adalah usaha yang dilakukan seseorang agar anak menyadari bahwa mereka masih memiliki kemampuan atau potensi yang dapat dikembangkan meski kemampuan atau potensi tersebut terbatas. 
Rehabilitasi adalah usaha yang dilakukan dengan berbagai macam bentuk dan cara, sedikit demi sedikit mengembalikan kemampuan yang hilang atau belum berfungsi optimal. Dalam kegiatan pembelajaran, guru hendaknya berusaha mengembangkan kemampuan atau potensi anak seoptimal mungkin, melalui berbagai cara yang dapat ditempuh.

\section{KESIMPULAN \\ Simpulan}

Simpulan yang dapat diajukan dalam penelitian ini adalah sebagai berikut:

a. Problematika guru PAI dalam kegiatan pembelajaran pada anak tunagrahita usia SD awal meliputi perencanaan, pelaksanaan dan penilaian pembelajaran. Perencanaan pembelajaran yang didesain pada RPP belum sepenuhnya dapat dilaksanakan sesuai perencanaan. Hal ini disebabkan oleh faktor kondisi anak yang berbeda-beda dari aspek karakteristik, minat dan kemampuan. Dalam pelaksanaannya, pembelajaran cenderung menggunakan pendekatan kontekstual yang digali berdasarkan situasi dan minat anak dibandingkan menggunakan pendekatan tematik yang sudah menjadi acuan dalam rancangan RPP. Sekalipun demikian, proses pembelajaran masih tampak monoton dan konvensional. Terlebih, metode ceramah lebih mendominasi metode yang lain, termasuk media yang digunakan lebih banyak menggunakan media yang dibawa oleh anak ke sekolah. Penilaian yang seharusnya bersifat individual sesuai kemampuan dan kebutuhan masing-masing anak, juga belum dapat dilaksanakan karena guru lebih fokus kepada bantuan bina diri anak. Sementara hasil belajar yang diujikan mengikuti standar ujian anak normal.

b. Problematika guru PAI dalam kompetensi meliputi kompetensi paedagogik dan kompetensi profesional. Kompetensi paedagogik yang berupa seperangkat keilmuan mendidik anak berkebutuhan khusus tidak dibekali oleh LPTK yang khususnya menghasilkan guru PAI. Dalam kompetensi profesional, guru PAI yang mempunyai beban mengajar melampaui beban wajib tidak memperoleh kompensasi dari pemerintah, sehingga pembelajaran PAI di SDLB kadang-kadang ditangani secara langsung oleh guru kelas.

c. Problematika guru PAI dalam mengembangkan sarana agama terkendala oleh faktor dana khususnya bantuan dari pemerintah (Kemenag). Pengembangan laboratorium agama lebih mengandalkan bantuan orang tua melalui sedekah/ infak.

\section{Rekomendasi}

Berdasarkan hasil temuan di lapangan, dapat dirumuskan rekomendasi dari penelitian ini sebagai berikut:

a. Pemerintah

Pemerintah hendaknya memperhatikan kondisi dan kebutuhan guru PAI yang 
diangkat oleh Kementerian agama melalui berbagai program bantuan pemerintah.

b. Sekolah

Pihak sekolah hendaknya memberikan kesempatan kepada guru PAI untuk memperoleh keilmuan yang berkaitan dengan pendidikan khusus melalui seminar, workshop dan sejenisnya guna meningkatkan kompetensi dan profesionalisme guru.

c. Guru

1) Guru hendaknya menentukan berbagai metode yang sesuai materi dan membuat media yang menarik dalam pembelajaran.

2) Guru hendaknya menampilkan sikap sabar, kasih sayang dan ramah pada anak agar tercipta suasana belajar yang nyaman dan menyenangkan.

\section{DAFTAR PUSTAKA}

Arifin.2001. Metodik Khusus Pendidikan Agama. Jakarta: Hidakarya.

Arikunto, Suharsimi. 1999. Manajemen Penelitian. Yogyakarta: Rineka Cipta.

Depdiknas. 2006. Pedoman Kbusus Penyelenggaraan Pendidikan Inklusif: Pedoman Kbusus Kegiatan Pembelajaran. Jakarta: Depiknas. 2006. Pedoman Khusus Penyelenggaraan Pendidikan Inklusif. Jakarta: Depdiknas.

E Woolfolk, Anita. . Educational Psycho and the Classroom Teacher. Boston: Allyn and Bacon.

M. Gagne, Robert. 1975. Essentials of Lerning for Instruction. Florida: Deiden Press.

Mohammad Ansyar. 2002. Kurikulum dalam Menyongsong Otonomi Pendidikan di Era Globalisasi, Peluang, Tantangan, dan Arah, dalam jurnal Pendidikan Islam TA'DIB, Maret 2002, (No. 04), ISSN 1401-6773, Fakultas Tarbiyah IAIN Raden Patah Palembnag.

Nasution. 2003. Metode Penelitian Naturalistik Kualitatif. Bandung: Remaja Rosdakarya, Edisi Revisi, Cet. 22.

Syah, Muhibbin. 2008. Psikologi Pendidikan dengan Pendekatan Baru. Bandung: Remaja Rosdakarya.

S. Nasution. 1984. Berbagai Pendekatan dalam Proses Belajar dan Mengajar. Jakarta: Bina Aksara.

S. Vargas, Julie. Behavioral Psychology for Teachers. New York: Harper and Row Publishers.

Zuhairini dkk. 2004. Metodologi Pengajaran Agama Islam. Jakarta: Pustaka Firdaus. 